\title{
Hubungan Somatotype dan Asupan Gizi Makro dengan Kebugaran Jasmani Atlet
}

\author{
Zulfah Rahmah $^{1 *}$, Defriani Dwiyanti ${ }^{2}$, Iswanelly Mourbas ${ }^{2}$, Eva Yuniritha $^{2}$, Kasmiyetti ${ }^{2}$ \\ ${ }^{1}$ Alumni Jurusan Gizi Poltekkes Kemenkes Padang \\ ${ }^{2}$ Dosen Jurusan Gizi Poltekkes Kemenkes Padang \\ Email : zulfahrahmah@gmail.com*
}

\section{ABSTRACT}

Physical fitness is factor to achieve achievement. Based on data of PPLP West Sumatra in 2018 is $30.6 \%$ of athletes included in the category less. Some factors that affect fitness are somatotype and nutritional intake. Somatotypes and balanced nutritional intake will support better sports performance This research aims to determine the correlation between somatotype and macronutrient intake with physical fitness.This research was conducted using a cross sectional design. The sampling method using total sampling method with a sample of 37 people. The intake data collection method uses $3 \times 24$ hour food recall, the somatotype is determined by the Heart Carter method and the fitness uses a bleep test. The data were analyzed using Chi-square statistical tests to see the correlation of somatotype with fitness and correlation pearson tests to see the correlation of macro nutrition intake with fitness. The results showed that the average fitness of athletes was $52.12 \mathrm{~mL} / \mathrm{kg} / \mathrm{min}$. The results showed an average fitness value of $52.12 \mathrm{~mL} / \mathrm{kg}$ / min and most were fit.. The average value of energy intake is $3471.71 \mathrm{kcal}$, protein intake of 88.50 $\mathrm{gr}$, fat intake is $97.02 \mathrm{gr}$, carbohydrate intake of $550.1 \mathrm{gr}$ ) water intake was $3253.54 \mathrm{ml}$ and most of the intake is good except water. Bivariate results showed that there was no significant relationship between somatotype and fitness but there was a significant relationship between macro nutrient intake and fitness. Further research is needed to find out other factors that affect fitness.

Keywords: Fitness; Somatotype; Macronutrient Intake

\section{PENDAHULUAN}

Olahraga saat ini telah menjadi kebutuhan dalam kehidupan manusia dan dapat dijadikan sebagai sarana pendidikan untuk pencapaian prestasi yang dilakukan melalui institusi profesional.(Rahmad, 2016).

Prestasi olahraga sepak bola di Pusat Pendidikan dan Latihan Pelajar (PPLP) Sumatera Barat, belum memberikan hasil yang baik dari setiap pertandingan yang pernah diikuti. Bedasarkan data PPLP Sumbar prestasi olahraga sepak takraw cenderung menurun.(PPLP Sumatera Barat, 2019)

Prestasi salah satunya dipengaruhi oleh kebugaran jasmani, Kebugaran jasmani yang prima sangat dibutuhkan untuk olahraga dengan tempo cepat dan berlangsung lama. Diantaranya yaitu olahraga permainan seperti: sepak bola dan sepak takraw.(Bryantara, 2016) 
Penelitian Novia (2018) bahwa tingkat kebugaran atlet di PPLP Sumatera Barat adalah termasuk kategori kurang 30,6 $\%$ dengan menggunakan bleep test.( Putri, 2018)

Kebugaran jasmani dipengaruhi oleh jenis kelamin, usia, asupan makanan, somatotype, aktifitas fisik dan rokok.(Wiarto, 2015) Salah satu faktor yang mempengaruhi yaitu somatotype. Somatotype adalah bentuk tubuh atau klasifikasi tipe tubuh manusia. Somatotype menilai komponen fisik tubuh manusia dengan tiga kategori yaitu : endomorf, mesomorf, dan ectomorf . Tipe endomorf cenderung gemuk, tipe mesomorf berotot dan tipe ektodermorf kurus. Somatotype atlet yang sesuai dengan cabang olahraga cenderung mendukung performa olahraga yang lebih baik.( Prakoso, 2014)

Somatotype atau bentuk tubuh untuk olahraga sepak bola dan sepak takraw memerlukan kesesuaian. Atlet sepak bola seharusnya memiliki bentuk tubuh balance mesomorf yaitu dimana bentuk tubuh atlet berotot dan sepak takraw dengan tipe tubuh ectomorphic mesomorph. Olahraga ini melakukan aktivitas berulang jangka pendek dan berintensitas tinggi berkaitan dengan kekuatan otot yang tinggi.(Penggalih et al., 2016)
Kebugaran jasmani juga didukung dengan asupan gizi sesuai kebutuhan. Seorang atlet yang mengonsumsi makanan yang mangandung nilai gizi seimbang akan mampu mempertahankan kondisi fisik secara prima.(Pertiwi \& Murbawani, 2012)

Hasil penelitian Anggitasari dkk (2018) didapatkan bahwa asupan energi dan somatotype merupakan variabel yang berhubungan dengan kebugaran jasmani.(Anggitasari et al., 2019) Hasil penelitian Emir dkk (2015) pada sebuah klub sepak bola menggunakan kuisoner untuk melihat hubungan asupan dengan kebugaran dengan menggunakan uji korelasi person didapatkan bahwa ada hubungan tingkat konsumsi energi, protein, lemak dan karbohidrat dengan tingkat kebugaran atlet sepak bola.(Bagustila, 2015)

Tujuan penelitian ini adalah untuk melihat hubungan somatotype dan asupan gizi makro dengan kebugaran jasmani pada atlet olahraga permainan di PPLP Sumatera Barat.

\section{METODE PENELITIAN}

Jenis penelitian adalah analitik dengan desain penelitian adalah cross sectional. Penelitian ini dilaksanakan pada bulan Juli 2019 di PPLP Sumatera Barat. Sampel penelitian ini adalah seluruh atlet olahraga permainan di PPLP Sumatera Barat yang 
berjumlah 37 orang. Variabel bebas peneltian ini adalah kebugaran jasmani. Sedangkan variabel terikat penelitian ini adalah somatotype dan asupan gizi makro.

Olahraga bedasarkan sistem energinya salah satunya adalah olahra aerobikanaerobik yaitu olahraga permaianan. Olahraga permainan adalah olahraga yang dilakukan dua tim dan saling memperebutkan kemenangan. Beberapa olahraga yang termasuk adalah sepak bola dan sepak takraw.

Metode pengambilan data asupan menggunakan food recall $3 \times 24$ jam, somatotype ditentukan dengan metode Heart Carter dan kebugaran menggunakan bleep test. Data yang diperoleh dianalisia dengan analisis univariat dan bivariat dengan menggunakan uji chi-square untuk melihat hubungan somatotype dengan kebugaran serta uji korelasi untuk melihat hubungan asupan gizi makro dengan kebugaran dengan tingkat kepercayaan $\mathrm{p}<0,05$.

\section{HASIL DAN PEMBAHASAN}

\section{a. Gambaran Responden Bedasarkan}

umur, jenis kelamin, status gizi, kebugaran, somatotype

Penelitian ini dilakukan terhadap atlet yang berjumlah 17 orang atlet sepak bola dan 20 orang atlet takraw. Lama responden menjadi atlet sepak bola dan sepak takraw di PPLP Sumatera Barat yaitu 1 - 3 tahun. . Gambaran umum responden yang dilihat meliputi : umur, jenis kelamin dan status gizi atlet. Gambaran umum dapat dilihat pada Tabel 1.

Tabel 1. Distribusi Frekuensi Responden Berdasarkan Umur, Jenis Kelamin dan Status Gizi Atlet Olahraga Permainan di di PPLP Sumbar

\begin{tabular}{|c|c|c|c|c|}
\hline Karakteristil & Sep & Bola & & \\
\hline 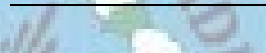 & $\mathrm{n}$ & $\%$ & $\mathrm{n}$ & $\%$ \\
\hline Umur & & & & \\
\hline 14 & 0 & 0 & 2 & 10 \\
\hline$=21$ & 0 & 0 & 6 & 30 \\
\hline 16 & 11 & 64,7 & 6 & 30 \\
\hline $17<=$ & 6 & 35,3 & 6 & 30 \\
\hline Jenis Kelamin & & & & \\
\hline Laki-laki & 17 & 100 & 15 & 75 \\
\hline Perempuan & 0 & 0 & 5 & 25 \\
\hline Status Gizi & & & & \\
\hline Gizi Kurang & 0 & 0 & 1 & 5 \\
\hline Normal & 17 & 100 & 18 & 90 \\
\hline Gizi Lebih & 0 & 0 & 1 & 5 \\
\hline $\begin{array}{l}\text { Tingkat } \\
\text { Kebugaran }\end{array}$ & & & & \\
\hline Bugar & 14 & 82,4 & 13 & 65 \\
\hline Tidak Bugar & 3 & 17,6 & 7 & 35 \\
\hline Somatotype & & & & \\
\hline Sesuai & 1 & 5,9 & 0 & 0 \\
\hline Tidak Sesuai & 16 & 94,1 & 20 & 100 \\
\hline Total & 17 & 100 & 20 & 100 \\
\hline
\end{tabular}


Tabel 1 menunjukkan bahwa umur respoden terbanyak yaitu 16 tahun $(45,9 \%)$. Sedangkan jenis kelamin respoden terbanyak yaitu laki-laki $(86,5 \%)$. Status gizi normal hampir dimiliki seluruh responden $(94,6 \%)$. Tingkat kebugaran atlet termasuk bugar 27 orang $(73 \%)$ dan tidak bugar yaitu 10 orang $(27 \%)$. Sedangkan somatotype yang sesuai dengan cabang olahraga sepak bola dan sepak takraw hanya 1 orang $(2,7 \%)$.

Penelitian ini dilakukan pada 37 atlet pada cabang sepak bola dan sepak takrw. Terdapat 32 atlet laki-laki dan 5 atlet perempuan. Penelitian ini untuk melihat hubungan somatotype dan asupan gizi makro dengan kebugaran atlet. Hasil penelitian didapatkan rata-rata $\mathrm{VO}_{2} \max$ atlet yaitu $52,12 \mathrm{~mL} / \mathrm{kg} / \mathrm{mnt}$ termasuk bugar 27 orang $(73 \%)$ dan tidak bugar yaitu 10 orang (27\%). Hasil penelitian ini sejalan dengan penelitian Novia (2018) terhadap atlet PPLP Sumatera Barat bahwa sebagian besar atlet memiliki kebugaran jasmani yang baik. (Tanjung, 2018). Atlet yang termasuk tidak bugar dikarenakan kondisi atlet yang sedang tidak prima.

Laki-laki dan perempuan memiliki kebugaran jasmani yang berbeda. Lakilaki memiliki kebugaran jasmani yang lebih besar dibandingkan perempuan. Ini berkaitan dengan kekuatan maksimal otot yang berhubungan luas dengan luas permukaan tubuh, komposisi tubuh, kekuatan otot, jumlah hemoglobin, hormon, kapasitas paru-paru, dan lainlain. (Wiarto, G. (2015)

Seseorang yang memiliki tingkat kebugaran jasmani yang baik merupakan jaminan saat melakukan aktifitas fisik tidak menimbulkan kelelahan yang bermakna. Latihan yang dilakukan harus mempertimbangkan kondisi kebugaran jasmani untuk menentukan volume latihan tepat. Volume latihan yang berlebihan dari kemampuan jasmani seseorang akan beresiko meningkatkan cidera. (Alamsyah, 2016)

Faktor-faktor yang mempengaruhi $\mathrm{VO}_{2}$ max diantaranya adalah somatotype. Somatotype atau bentuk tubuh adalah keadaan tubuh dari seseorang yang sangat menentukan atau cocok karena sangat memungkinkan untuk melakukan aktivitas fisik terhadap suatu cabang olahraga tertentu. (Hapsari, 2019)

Hasil pengukuran somatotype pada atlet olahraga sepak bola didapatkan bahwa ada 1 orang $(2,7 \%)$ yang memiliki somatotype balance mesomorph dan tidak ada atlet sepak takraw yang memiliki somatotype yang sesuai yaitu ectomorphic mesomorhp. Jika dibandingkan dengan 
hasil penelitian somatotype atlet semi profesional hingga profesional dengan cabang olahraga yang sama didapatkan hasil yang berbeda. Penelitian ini tidak sejalan dengan hasil penelitian Salgado (2009) bahwa atlet sepak bola remaja di Potugal termasuk balance mesomorf.

Beberapa faktor yang mempengaruhi hasil somatotype yang diukur belum sesuai dengan yang diharapkan. Ketidaksesuaian ini kemungkinan karena adanya perbedaan program latihan, intervensi diet dan umur atlet yang masih remaja. (Hapsari, 2019) Cara untuk merubah atlet sesuai dengan tipe tubuh yang diharapkan dengan latihan membentuk massa otot dan intervensi diet yang tepat.

\section{b. Hubungan Somatotype dengan} Tingkat Kebugaran

Bedasarkan hasil penelitian, hubungan somatotype dengan tingkat kebugaran pada atlet PPLP Sumatera Barat dapat dilihat pada Tabel 2.

Tabel 2. Hubungan Somatotype dengan Tingkat Kebugaran Atlet Olahraga Permainan di di PPLP Sumbar

\begin{tabular}{|c|c|c|c|c|c|c|c|}
\hline \multirow{3}{*}{$\begin{array}{l}\text { Kategori } \\
\text { Somatot } \\
\text { ype }\end{array}$} & \multicolumn{4}{|c|}{ Kategori Kebugaran } & \multirow{2}{*}{\multicolumn{2}{|c|}{ Total }} & \multirow[t]{3}{*}{$\mathbf{p}$} \\
\hline & \multicolumn{2}{|c|}{ Bugar } & \multicolumn{2}{|c|}{$\begin{array}{c}\text { Tidak } \\
\text { Bugar }\end{array}$} & & & \\
\hline & $\mathbf{n}$ & $\%$ & $\mathbf{n}$ & $\%$ & $\mathbf{n}$ & $\%$ & \\
\hline Sesuai & 1 & 2,7 & 0 & 0 & 1 & 2,7 & 1,00 \\
\hline $\begin{array}{l}\text { Tidak } \\
\text { Sesuai }\end{array}$ & 26 & 70,3 & 10 & 27 & 36 & 97,3 & \\
\hline Total & 27 & 73 & 10 & 27 & 37 & 100 & \\
\hline
\end{tabular}

Bedasarkan tabel 2 bahwa atlet yang tidak mempunyai somatotype sesuai dengan cabang olahraga yang termasuk kategori bugar lebih tinggi dibandingkan atlet dengan somatotype yang sesuai dengan kategori bugar.

Hasil uji statistik didapatkan bahwa $p$ value yaitu 1,00 ( $p>0,05)$, maka dapat ditarik kesimpulan bahwa tidak terdapat hubungan somatotype dengan kebugaran jasmani atlet. Penelitian ini tidak sejalan dengan penelitian Anggita, dkk (2019) bahwa terdapat hubungan somatotype dengan kebugaran jasmani atlet. (Anggitasari et al., 2019)

Faktor-faktor yang menyebabkan tidak ada hubungan antara somatotype dengan kebugaran jasmani atlet antara lain : aktivitas atlet yang tinggi, intervensi diet yang tidak tepat, umur yang masih remaja dan pengaruh variabel perancu yaitu jenis kelamin. (Hapsari, 2019)

Bedasarkan penelitian didapatkan bahwa sebagian besar somatotype atlet tidak sesuai dengan olahraga namun memiliki kebugaran yang baik. Hal ini dikarenakan bahwa aktifitas atlet termasuk kategori tinggi. Hal ini sejalan dengan penelitian Mailinia (2019) tentang Kualitas diet dan daya tahan (endurance) Atlet Bulutangkis Remaja di Kota Semarang bahwa sebagian besar atlet 
memiliki aktifitas yang tinggi sehingga tingkat kebugaran atlet baik. (Mailina, 2019)

Penentuan cabang olahraga yang sesuai dengan tipe tubuh sangat penting agar atlet dapat memilih aktivitas fisik atau cabang olahraga yang dapat dilakukan secara maksimal. Somatotype atlet yang sesuai dengan cabang olahraga yang ditekuni ternyata sangat mendukung performa atlet.

\section{d. Tingkat Kecukupan Asupan dan} Hubungan Asupan Gizi Makro dengan Nilai Kebugaran Jasmani Atlet

Tingkat konsumsi atlet dapat dilihat pada Tabel 3 berikut ini :
Tabel 3. Distribusi Frekuensi Responden Berdasarkan Asupan Energi, Protein, Lemak, Karbohidrat dan Air Atlet Olahraga Permainan di PPLP Sumbar

\begin{tabular}{|c|c|c|c|c|}
\hline \multirow[t]{2}{*}{ Karakteristik } & \multicolumn{2}{|c|}{ Sepak Bola } & \multicolumn{2}{|c|}{ Sepak Takraw } \\
\hline & $\mathrm{n}$ & $\%$ & $\mathrm{n}$ & $\%$ \\
\hline \multicolumn{5}{|l|}{ Asupan Energi } \\
\hline Kurang $(\leq 90 \%)$ & 5 & 29,4 & 2 & 10 \\
\hline Baik(90-100) & 12 & 70.6 & 18 & 90 \\
\hline $\operatorname{Lebih}(>110 \%)$ & 0 & 0 & 0 & 0 \\
\hline \multicolumn{5}{|l|}{ Asupan Protein } \\
\hline Kurang $(\leq 90 \%)$ & 5 & 29,4 & 2 & 10 \\
\hline Baik(90-100) & 9 & 52,9 & 12 & 60 \\
\hline $\operatorname{Lebih}(>110 \%)$ & 3 & 17,6 & 6 & 30 \\
\hline \multicolumn{5}{|l|}{ Asupan Lemak } \\
\hline Kurang $(\leq 90 \%)$ & 3 & 17,6 & 6 & 30 \\
\hline Baik(90-100) & 13 & 76,5 & 12 & 60 \\
\hline $\operatorname{Lebih}(>110 \%)$ & 1 & 5,9 & 2 & 10 \\
\hline \multicolumn{5}{|c|}{ Asupan Karbohidrat } \\
\hline Kurang $(\leq 90 \%)$ & 9 & 52,9 & 5 & 25 \\
\hline Baik(90-100) & 7 & 41,2 & 15 & 75 \\
\hline Lebih $(>110 \%)$ & 1 & 5,9 & 0 & 0 \\
\hline \multicolumn{5}{|l|}{ Asupan Air } \\
\hline Kurang( $\leq 90 \%)$ & 9 & 52,9 & 10 & 50 \\
\hline $\operatorname{Baik}(90-100)$ & 8 & 47,1 & 10 & 50 \\
\hline Lebih $(>110 \%)$ & 0 & 0 & 0 & 0 \\
\hline Total & 17 & 100 & 20 & 100 \\
\hline
\end{tabular}

Bedasarkan tabel 3 dapat dilihat

bahwa tingkat kecukupan energi,protein, lemak, karbohidrat pada atlet sebagian besar termasuk kategori baik, kecuali tingkat kecukupan asupan air pada air termasuk kurang.

Bedasarkan hasil penelitian, hubungan asupan energi, zat gizi makro dengan nilai kebugaran $\left(\mathrm{VO}_{2} \max \right)$ pada atlet PPLP Sumatera dapat dilihat pada Tabel 4 berikut ini : 
Tabel 4. Hubungan Asupan Energi, Protein, Lemak Karbohidrat dan Air dengan Nilai Kebugaran Atlet Olahraga Permainan di di PPLP Sumbar

\begin{tabular}{lcc}
\hline $\begin{array}{l}\text { Variabel } \\
\text { Independen }\end{array}$ & & $\mathrm{VO}_{2}$ max \\
\hline Asupan Energi & $\mathrm{R}^{*}$ & $\mathrm{P}$ \\
Asupan Protein & 0,661 & 0,000 \\
Asupan Lemak & 0,452 & 0,005 \\
Asupan & 0,469 & 0,003 \\
Karbohidrat & & \\
Asupan Air & 0,704 & 0,000 \\
Asupan Energi & 0,624 & 0,000 \\
\hline
\end{tabular}

*Uji Korelasi Pearson

Bedasarkan tabel 4 dapat dilihat Hubungan asupan energi, protein, lemak karbohidrat dan air dengan $\mathrm{VO}_{2}$ max.

Hasil uji statistik rata-rata asupan dengan $\mathrm{VO}_{2}$ max diperoleh nilai korelasi positif yang artinya semakin baik asupan maka semakin tinggi nilai $\mathrm{VO}_{2} \max$ atlet. Sedangkan hubungan asupan gizi makro dengan $\mathrm{VO}_{2}$ max didapatkan nilai p yaitu $0,000(\mathrm{p}<0,05)$, maka dapat disimpulkan ada hubungan antara asupan gizi makro dengan $\mathrm{VO}_{2} \max$.

Bedasarkan uji korelasi pearson didapatkan $r$ sebesar 0,64 dan nilai $p$ sebesar $0,00(\mathrm{p}<0,05)$ yang artinya ada hubungan bermakna antara asupan energi dengan $\mathrm{VO}_{2}$ max atlet olahraga permainan di PPLP Sumatera Barat. Hasil penelitian ini sejalan dengan penelitian Bagustila bahwa ada Hubungan signifikan antara tingkat konsumsi energi dengan tingkat kebugaran atlet sepak bola Jember United FC. (Bagustila, 2015)

Asupan zat gizi makro atlet didapatkan dengan menggunakan recall 3x24 jam, dimana dua kali dilakukan mewakili hari latihan dan satu kali dilakukan untuk mewakili hari libur latihan atlet.

Salah satu faktor penting untuk mencapai prestasi olahraga yang penting adalah memenuhi gizi seimbang. Makanan harus disesuaikan dengan jenis dan durasi latihan sehingga energi yang dikeluarkan untuk olahraga seimbang dengan energi yang masuk dari makanan. (Ramacahya et al., 2010)

Energi dibutuhkan masing-masing individu untuk memenuhi kebutuhan energi basal, menunjang proses pertumbuhan dan untuk aktivitas seharihari. Energi dapat diperoleh dari protein, lemak dan karbohidrat yang terdapat pada bahan makanan.(Elvia, 2018)

Hasil penelitian didapatkan bahwa sebagian besar asupan lemak atlet termasuk kategori baik. Hasil penelitian ini sejalan dengan Hasil Penelitian Novia (2018) yang dilakukan pada atlet PPLP Sumatera Barat bahwa sebagian besar atlet termasuk kategori baik. (Tanjung, 2018)

Hasil penelitian didapatkan bahwa sebagian besar termasuk kategori baik. 
Penelitian ini sejalan dengan penelitian yang dilakukan penelitian Bagustila pada atlet sepak bola Jember United FC sebagian besar atlet termasuk kategori baik.(Bagustila, 2015)

Otot rangka selama aktivitas fisik dapat bergantung pada oksidasi lemak atau karbohidrat untuk memenuhi kebutuhan energi. Pada kondisi istirahat, oksidasi lemak akan berkontribusi lebih dalam penyediaan energi.(Hapsari, 2019)

Karbohidrat dibutuhkan untuk menjaga gula darah saat berolahraga, menggantikan simpanan glikogen setelah latihan. Jumlah simpanan glikogen yang terdapat di dalam tubuh adalah salah satu faktor yang menentukan performa atlet.(AASP. Chandradewi, 2017). Atlet yang tidak mengkonsumsi karbohidrat secara cukup setiap hari, maka simpanan glikogen otot dan hati akan menurun dan berpengaruh pada penurunan daya tahan dan performa atlet. (Rizqi \& Udin, 2018)

Bedasarkan hasil penelitian asupan protein sebagian besar termasuk kategori baik. Hasil penelitian ini sejalan dengan Penelitian Komaruddin (2011) yang dilakukan pada atlet sepak bola dan sepak takraw di PPLP Provinsi Sulawesi Selatan didapatkan sebagian besar atlet termasuk kategori baik.(Agustin et al., 2018)
Protein bagi atlet remaja sangat dibutuhkan untuk pertumbuhan dan membentuk tubuh untuk mencapai tinggi badan yang optimal. Protein digunakan selama aktivitas fisik tidak menjadi sumber energi utama seperti penggunaan lemak dan karbohidrat. Namun, atlet membutuhkan protein lebih tinggi dibandingkan dengan non atlet. Atlet memerlukan protein untuk membantu proses adaptasi akibat latihan, memperbaiki serabut otot yang rusak, dan pembentukan enzim-enzim. Protein yang berfungsi sebagai bahan pembentuk jaringan baru dan memperbaiki serabut otot yang rusak sangat diperlukan seorang atlet yang berlatih intensif dan lama sehingga kebugaran jasmani dapat dipertahankan dengan baik. (Hanum, 2011)

Hasil penelitian didapatkan bahwa asupan air sebagian besar atlet termasuk kategori kurang. Penelitian ini sejalan dengan penelitian Ramadhan dkk tentang Hubungan antara Status Hidrasi Serta Konsumsi Cairan Pada Atlet Bola Basket didapatkan bahwa sebagian besar asupan air atlet termasuk kategori kurang. (Ramadhan \& Rismayanthi, 2005)

Asupan air sangat penting bagi seorang atlet karena menentukan kinerja termasuk daya tahan atlet selama latihan 
dan bertanding. Minuman selain bermanfaat menggantikan cairan yang hilang juga berfungsi mengurangi panas badan dan memberi kesempatan penambahan karbohidrat. Atlet yang asupan air yang kurang akan beresiko mengakibatkan daya tahan yang kurang. (Kinasih, 2019) Secara umum, cairan yang disarankan untuk atlet adalah air mineral, minuman elektrolit, minuman yang mengandung karbohidrat dan minuman yang mengandung protein. (Penggalih et al., 2019)

Kandungan air dalam sel otot lebih tinggi daripada kandungan air di dalam sel lemak, sehingga cairan tubuh total pada orang berbadan gemuk lebih rendah dibandingkan orang berbadan kurus. Kandungan air yang dibutuhkan atlet lebih banyak dari non atlet karena tubuh memiliki relatif banyak otot yang mengandung banyak air. (Kinasih, 2019)

\section{KESIMPULAN}

Tidak ada hubungan somatotype dengan kebugaran jasmani atlet. Sedangkan pada asupan gizi makro terdapat hubungan antara energi, protein, lemak, karbohidrat dan air dengan kebugaran jasmani atlet dengan $\mathrm{p}<0,05$.

\section{UCAPAN TERIMAKASIH}

Terima kasih diucapkan kepada pelatih dan atlet olahraga permainan PPLP
Sumatera Barat yang telah bersedia menjadi sampel penelitian, Jurusan Gizi Poltekkes Padang yang telah memfasilitasi penelitian ini.

\section{DAFTAR PUSTAKA}

AASP. Chandradewi, I. (2017). Asupan energi, protein, dan stamina atlet di pusat pendidikan dan latihan olahraga pelajar Nusa Tenggara Barat. Journal of Chemical Information and Modeling, 11(1), 28-35.

https://doi.org/10.1017/CBO978110 7415324.004

Agustin, Y., Indra, E. N., \& Afriani, Y. (2018). Asupan protein dan somatotype pada atlet pencak silat di Pembinaan Atlet Berbakat Yogyakarta. Ilmu Gizi Indonesia, 1(2),

https://doi.org/10.35842/ilgi.v1i2.37
Alamsyah, D. (2016). Somatotype dan kebugaran motorik peserta ekstrakurikuler putra di smk bina harapan ngaglik Sleman Yogyakarta. Universitas Negeri Yogyakarta.

Anggitasari, E. D., Dieny, F. F., \& Candra, A. (2019). Hubungan somatotype dengan kesegaran jasmani atlet sepak 
bola. Jurnal Keolahragaan, 7(1), 11-

22.https://doi.org/10.21831/jk.v7i1.2 1188

Anindito Suryo Prakoso. (2014). Profil somatotype unit kegiatan mahasiswa sepak bola Universitas Gajah Mada (Gama). Universitas Negeri Yogyakarta.

Bagustila, E. (2015). Konsumsi Makanan, Status Gizi dan Tingkat Kebugaran Atlet Sepak Bola Jember United FC. Universitas Jember.

PPLP Sumatera Barat. (2019). Data Prestasi Atlet.

Bryantara, O. F. (2016). Faktor yang berhubungan Dengan kebugaran jasmani (Vo2Maks) atlet sepak bola. Jurnal Berkala Epidemiologi, 4(2), 237-249.

https://doi.org/10.20473/jbe.v4i2.20 16.237

Elvia, Siti fatimah, S. . N. (2018). Hubungan Gaya Hidup, Status Gizi Dan Aktivitas Fisik Dengan Tingkat Kesegaran Jasmani (Studi Pada Atlet Softball Perguruan Tinggi Di Semarang Tahun 2017). Jurnal
Kesehatan Masyarakat (e-Journal), 6(1), 449-457.

Hanum, F. (2011). Hubungan karakteristik atlet, pengetahuan gizi, konsumsi pangan, dan tingkat kecukupan gizi terhadap kebugaran atlet bola basket di smp/sma ragunan Jakarta Selatan. Institut Pertaninan Bogor.

Hapsari, M. dkk. (2019). Sistem energi, antropometri dan asupan makan atlet. Gajah Mada University Press.

Kinasih, A. C. (2019). Faktor-faktor yang berhubungan dengan kebugaran jasmani atlet sepak bola remaja. Universitas Diponegoro.

Mailina, D. (2019). Kualitas diet dan daya tahan (endurance) atlet bulutangkis remaja di. Journal of Nutrition College, 8, 29-37.

Mashar, M. A. (2012). Analisis Pelaksanaan manajemen pusat pembinaan dan latihan olahraga pelajar (pplp) pencak silat jawa tengah. Universitas Sebelas Maret.

Muizzah, L. (2013). Hubungan antara 
Kebugaran dengan Status Gizi Dan

Aktivitas Fisik pada Mahasiswi

Program Studi Kesehatan

Masyarakat UIN Syarif Hidayatullah

Jakarta Tahun 2013. UIN Syarif

Jakarta.

Penggalih, M. H. S. T., Dewinta, M. C. N.,

Solichah, K. M., Pratiwi, D.,

Niamilah, I., Nadia, A., \&

Kusumawati, M. D. (2019).

Identifikasi status gizi, somatotipe, asupan makan dan cairan pada atlet atletik remaja di Indonesia. Journal of Community Empowerment for

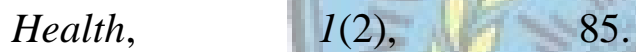
https://doi.org/10.22146/jcoemph.38 410

Penggalih, M. H. S. T., Pratiwi, D., Fitria, F., Sari, M. D. P., Narruti, N. H., Winata, I. N., Fatimah, \& Kusumawati, M. D. (2016). Identifikasi Somatotype, status gizi dan dietary Atlet remaja stop dan go sport. 4(1), 44-47.

Pertiwi, A. B., \& Murbawani, E. A. (2012). Pengaruh Asupan Makan (Energi, Karbohidrat, Protein dan Lemak) terhadap Daya tahan jantung paru atlet sepak bola. Journal of
Nutrition College, 1(1), 111-117. https://media.neliti.com/media/publi cations/185001-ID-pengaruhasupan-makan-energikarbohidrat.pdf\%0A

Rahmad, H. (2016). Pengaruh penerapan daya tahan kardivaskuler (Vo Max) dalam permaian Sepakbola Ps Bina Utama. Curricula, 2(2), 1-10. https://doi.org/10.22216/jcc.v2i2.10 09

Ramacahya, M., Mury, K., \& Dudung, A. (2010). Asupan Energi dan Zat Gizi Makro, Kebiasaan Merokok, Konsumsi Alkohol dan Kuantitas Tidur Terhadap kebugaran dan Keterampilan Shooting atlet Basket ASPAC Jakarta. Gizi.

Ramadhan, R. I., \& Rismayanthi, C. (2005). Hubungan Antara Status Hidrasi Serta Konsumsi Cairan Pada Atlet Bola Basket. Medikora, VX(April), 53-69.

Rizqi, H., \& Udin, I. (2018). Hubungan Asupan Karbohidrat Dan Status Gizi Dengan Tingkat Kebugaran Jasmani Pada Atlet Basket Remaja Siswa Sekolah Menengah Pertama. Media 
Gizi Indonesia, 11(2), 182.

https://doi.org/10.20473/mgi.v11i2.1

$82-188$

Tanjung Nova Putri. (2018). Hubungan

asupan zat gizi makro dan persen

lemak tubuh dengan nilai kebugaran

jasmani atlet di uptd kebakatan

olahraga Provinsi Sumatera Barat.

Universitas Andalas.

Wiarto, G. (2015). Panduan berolahraga untuk kesehatan dan kebugaran (1st ed.). Graha Ilmu.

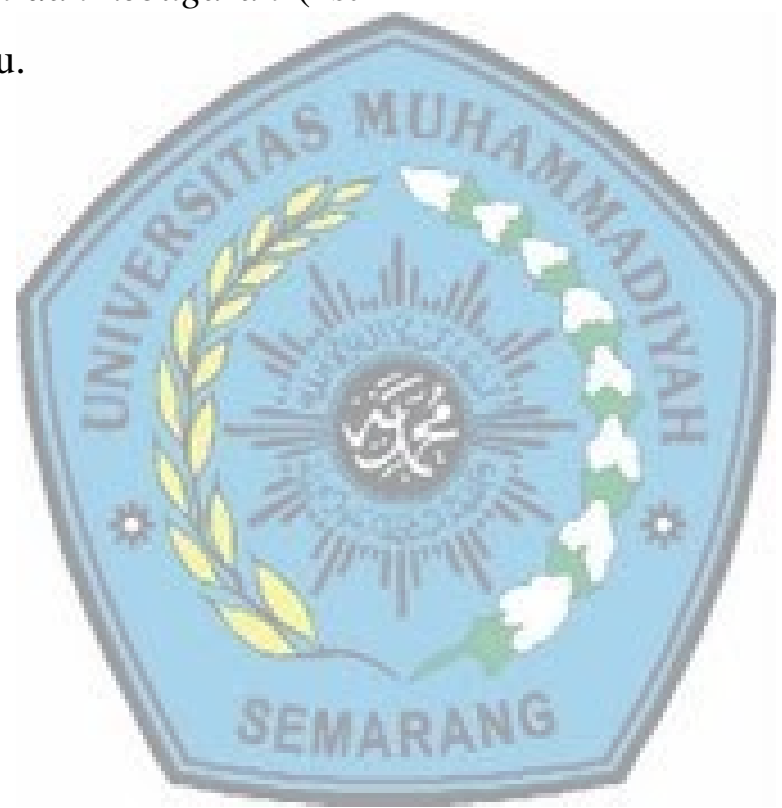

